\title{
ДИАГНОСТИЧЕСКИЙ ПОДХОД ПРИ ПИРОПЛАЗМОЗЕ ЛОШАДЕЙ В ПРИМОРСКОМ КРАЕ
}

\author{
Любченко Елена Николаевна \\ к.в.н., доцент \\ Болтенко Дарья Константиновна \\ ФГБОУ ВО «Приморская государственная \\ сельскохозяйственная академия»
}

\begin{abstract}
Аннотация: Приморский край является неблагополучным регионом по пироплазмидозам, поэтому очень важным является ранняя диагностика этих заболеваний. Данная научная работа проводилась в рамках проведения исследования по поиску эффективных методов лечения пироплазмоза лошадей в условиях Приморского края. В нашем крае самым распространенным методом диагностики пироплазмоза у лошадей является исследование мазков крови из периферических сосудов.
\end{abstract}

Ключевые слова: Пироплазмоз, диагностика, лошади, Приморский край.

\section{DIAGNOSTIC APPROACH FOR PIROPLASMOSIS HORSES IN THE PRIMORSKY KRAI}

\section{Lyubchenko Elena Nikolaevna Boltenko Daria Konstantinovna}

\begin{abstract}
The Primorsky Krai affected by piroplasmosis, so early diagnosis of these diseases is very important. This research was carried out as part of investigation of effective methods of treating equine piroplasmosis in the Primorsky Krai. In our region the most common method for diagnosing equine piroplasmosis is the examination of peripheral blood smear.
\end{abstract}

Key words: Piroplasmosis, diagnostics, horses, Primorsky Krai.

Пироплазмидозы - большая группа инвазионных болезней, вызываемых простейшими, локализующимися в эритроцитах и клетках мононуклеарных 
фагоцитов. У непарнокопытных в группу пироплазмидозы входят два заболевания: пироплазмоз (бабезиоз) и нутталлиоз (тейляриоз) [1, с.58]. Пироплазмидозы лошадей наносят существенный ущерб коневодству в пастбищный период, снижая на длительный срок продуктивность животных, угнетая их воспроизводительную функцию.

Первое описание возбудителя лошадей в 1906 и 1090 годах принадлежит Белицеру. В 1910 год Nuttal и Strickland провели сравнительное изучение паразитов, вызывающих маляриеподобных заболевание лошадей, и четко разделили их на два вида. Возбудителя, описанного Лавераном, они отнесли к Piroplasma equi (Piroplasma equi, Laveran,1901), а паразита, описанного Белицером в России, назвали Babesia caballi (Piroplasma caballi, Nuttal, Strickland,1910) [2, c.91].

В России заболевание, сходное с пироплазмозом, также описали А. Попов (1892) на Кавказе и В. Михайлов (1903) в Смоленской губернии. По утверждению К.П. Юрова, за возникновения пироплазмоза лошадей могут быть ответственными два отдельных патогенна [8, с. 192].

По информации А.А. Стекольникова [6, с.527], для пироплазмоза характерна трансмиссивная передача, распространение болезни напрямую связано с ареалом жизнедеятельности его специфических переносчиков клещей рода Dermacentor (кожерез), Hyalomma (стеклоглаз), Rhipicephalus (веероголов), которые постепенно заселяют новые территории, формируя новые очаги заболеваний. Распространено в Южной и Северной Америке, странах Карибского бассейна, Южной Европе, некоторых районах Африки, Азии и Среднего Востока. Тотальное распространение клещей-переносчиков данной группы заболеваний привело к тому, что болезни регистрируют во всех федеральных округах Российской Федерации.

Природно-климатические условия способствуют появлению клещей, которые являются переносчиками пироплазмоза, так как они широко распространены в регионах с умеренным климатом [5, с.179]. По данным Управления Роспотребнадзора, по числу людей, заболевших болезнями, передающимися иксодовыми клещами, Приморский край относится к числу неблагополучных территорий в Российской Федерации. По данным оперативного мониторинга Роспотребнадзора по Приморскому краю, в 2019 году наибольшее количество обратившихся по поводу укусов клещей регистрировалось в Артёмовском и Уссурийском городских округах, Хасанском, Лазовском, Кавалеровском, Пожарском районах [7, электр. 
pecypc]. Сезонная динамика пироплазмоза лошадей в основном зависит от климатических условий. В средних широтах наблюдаются весенняя и осенняя вспышки болезни и на юге - летняя [6, с.529].

Актуальность разработки новых средств диагностики пироплазмидозов лошадей в Российской Федерации связана с обеспечением безопасности при импорте племенных и спортивных лошадей из стран, неблагополучных по заболеванию, для минимизации денежных затрат и дополнительных временных потерь при движении конского поголовья. Поскольку на сегодняшний день не разработано эффективных препаратов, позволяющих предотвратить распространение данной инвазии, основными методами борьбы с пироплазмозом является его ранняя диагностика. Данная научная работа проводится в рамках проведения исследования эффективных методов лечения пироплазмоза лошадей в условиях Приморского края.

Целью нашего исследования является изучение методов диагностики пироплазмоза, применяемых в Приморском крае.

Для достижения цели были поставлены следующие задачи:

1) провести анализ лабораторных методов диагностики пироплазмоза лошадей за рубежом и в Российской Федерации;

2) изучить особенности диагностики пироплазмоза лошадей в Приморском крае.

Материалы и методы. Для установления методов диагностики пироплазмоза лошадей в Российской Федерации и за рубежом, изучали литературные источники и статьи.

С целью выяснения, на основании чего ставится диагноз на пироплазмоз, анализировали результаты исследований ФГБУ «Межобластная ветеринарная лаборатория» на территории Уссурийского городского округа Приморского края. Также использовали информацию ветеринарных специалистов и владельцев конных клубов.

Результаты исследования. Диагноз на пироплазмоз ставят комплексно, на основании эпизоотологических данных, наличия клещей-переносчиков, сезона распространения, клинической и патологоанатомической картины, а также лабораторных исследований.

В мировой практике для диагностики пироплазмоза животных применяют ферментзависимый иммуносорбционный анализ (ELISA) и иммуноферментный анализ (ИФА). Впервые метод ELISA применил G. Weiland в 1986 году. Он успешно использовался для дифференциальной 
диагностики Т.equi и B.caballi. [11, c.881]. В 2007 году A.Alhassan и Y.Govind разработали LAMP-тесты, нацеленные на гены T.equi и B.caballi, и сообщили, что они обладают более высокой эффективностью обнаружения по сравнению с культурами in vitro и традиционной ПЦР. Еще предстоит изучить возможность использования LAMP для крупномасштабных эпидемиологических исследований. Однако эти диагностические тесты на основе ДНК до сих пор не используются в диагностических целях в странах с ограниченными ресурсами, где пироплазмидозы носят эндемический характер [9, пункт 14.7].

В нашей стране техника ИФА была разработана в 1990 году В.В.Петровским и С.Н.Малышевым, однако они отмечают неудовлетворительную специфичность этих методов из-за перекрестных реакций с другими представителями типа Apicomplexa. [1, c.61].

Поэтому тест на связывание комплемента (РСК) остается предпочтительным серологическим тестом для подтверждения пироплазмоза, в недавнем прошлом это был официально приемлемый тест, рекомендованный Всемирной организацией по охране здоровья животных для проверки лошадей перед въездом в страны, благополучные по пироплазмидозам. [10, с.480]

Диагностические методы на основе ДНК - обнаружение патогенов с помощью полимеразной цепной реакции (ПЦР) более чувствительно, чем любые другие методы, и лучше всего подходит для диагностики животных с хронической инфекцией. Он широко используется в исследовательских учреждениях, улучшает диагностические результаты и поэтому рассматривается как дополнение к микроскопии и серологии.

В России микроскопия мазка остается пока еще преимущественным методом диагностики пироплазмидозов. По данным А.А. Кудряшова, диагноз подтверждают микроскопическим исследованием крови, взятой у больной лошади, возможно исследование крови и у павшей лошади [3, с.109]. Серологические методы, такие как РСК, РДСК, РИФ, ИФА, ELISA, используются реже. Также проходит апробацию тест-система, позволяющая идентифицировать ДНК-возбудителей пироплазмоза и нутталлиоза. Важным преимуществом разрабатываемой системы является ее пригодность для массового скрининга [1, с.62].

Умеренный климат и природные условия юга Приморского края благоприятно влияют на размножение иксодовых клещей, являющихся переносчиками Piroplasma caballi, а конюшенно-табунное содержание 
способствуют заражению лошадей пироплазмозом, поэтому вспышки могут отмечаться весной, когда наступает их биологическая активность, и осенью с появлением осенней генерации [4, c.59]. При укусе со слюной клеща пироплазмы попадает в кровь животного и начинает активно размножаться в эритроцитах, вызывая их разрушение, сопровождающееся гемоглобинемией, гемоглобинурией, желтухой и анемией. При этом высвобождается большое количество токсичных веществ, действие которых и обуславливает клиническую картину болезни [3, с.108].

По информации ветеринарных специалистов и владельцев лошадей (КСК «Грация», «Кочевник», конный клуб «Частный дворик» и др.), чаще весной или осенью, через 8-10 дней после укуса клещей у лошадей наблюдали быструю утомляемость, отсутствие аппетита, повышение температуры тела, учащенные дыхание и пульс, колики и метеоризм кишечника. Если животному не проводили лечение, то появлялись анемия и желтушное окрашивание конъюнктивы глаз, наступала гибель от отека легких. Первым и главным этапом в лечении пироплазмоза является его лабораторное подтверждение. Дело в том, что клинические признаки этого заболевания очень схожи с признаками нутталиоза и лептоспироза, который часто регистрируется на территории края.

На территории Приморского края сеть ветеринарных лабораторий представлена ФГБУ «Приморская межобластная ветеринарная лаборатория» и пятью лабораториями краевой ветеринарной службы. Исследования на пироплазмоз лошадей проводятся в ФГБУ «Приморская МВЛ», где имеется современное высокотехнологичное оборудование, а также применяется в работе метод полимеразной цепной реакции (ПЦР).

Диагноз на пироплазмоз лошадей в данном регионе ставится на основании эпизоотологических данных, клинической картины и подтверждается результатами лабораторных исследований.

Для исследований на пироплазмоз в Приморском крае в лабораторию направляют тонкие мазки крови из периферических сосудов уха или хвоста животного. Мазки крови стараются сделать в период развития симптомов болезни, при повышенной температуре, до применения специфического лечения. Подготовку мазков начинают с обезжиривания предметного стекла спирт-эфирным раствором, затем помещают обязательно первую каплю крови на край предметного стекла и аккуратно размазывают с помощью второго стекла, которое скользит по первому. Перед окрашиванием 
изготовленный мазок высушивают на воздухе покачиванием предметного стекла, что позволяет избежать формирования светлой неокрашенной зоны в центре эритроцитов и, соответственно, исключить ошибочную интерпретацию гипохромии. Приготовленные мазки упаковываются попарно, так, чтобы мазки располагались на противоположных сторонах предметных стекол в чистую не пористую бумагу. В случае отсутствия возможности предоставить мазок крови на стекле, в лабораторию отправляют кровь в пробирке, содержащей Трилон Б (стабилизатор крови), который блокирует реакцию свертывания крови, при этом оставляя неизменными концентрацию и характеристики клеточных и внеклеточных компонентов. У павших лошадей мазки крови берут из подкожных сосудов венчика копыта конечности, где возбудители могут храниться до шести суток. Все упакованные материалы направляются в лабораторию в день их отбора. Окраску проводят стандартным методом в условиях лаборатории. В мазках цельной крови, окрашенных по Романовскому-Гимза, обнаруживают характерные формы возбудителя. Другие методики исследования лошадей на пироплазмоз, кроме микроскопии мазка периферической крови, в ветеринарных лабораториях не территории Приморского края не применяют.

В зарубежных странах и России для диагностики пироплазмоза животных применяют методики с использованием ферментзависимого иммуносорбционного анализа (ELISA), иммуноферментного анализа (ИФА), полимеразной цепной реакции (ПЦР). На территории Приморского края функционирует шесть ветеринарных лабораторий, одна из которых оснащена оборудованием для проведения полимеразной цепной реакции (ПЦР). Диагноз на пироплазмоз лошадей в данном регионе ставится на основании эпизоотологических данных, клинической картины и лабораторно подтверждается только результатами исследования мазка крови из периферических сосудов. В связи с периодическим выявлением лошадей, больных пироплазмозом и своевременной диагностике, необходимо оснащать ветеринарные лаборатории необходимым оборудованием, расширять спектр услуг в данном направлении, что значительно повысит эффективность и своевременность лечения больных животных, а также улучшит имидж лабораторий. 


\section{Список литературы}

1. Калашникова, Т.В. Бабезиозы лошадей: этиология и проблемы диагностики / Т.В. Калашникова, Л.А. Храброва // VetPharma. - 2015. - №1. C.58-62.

2. Крылов, М.В. Возбудители протозойных болезней домашних животных и человека: в 2 т. Т.2 / М.В. Крылов; Зоологический институт РАН. - СПб.: ЗИН РАН, 1994.- 267 с.: ил., табл.

3. Кудряшов, А.А. Патологоанатомическая диагностика болезней лошадей: учеб. пособие / А.А. Кудряшов. - СПб.: Институт Ветеринарной Биологии, 2012. - 108 с. - (Ветеринарная патологическая анатомия). - ISBN 978-5-9902656-3-9.

4. Паразитология и паразитарные болезни сельскохозяйственных животных: учебник / Н.Е. Косминков, Б.К. Лайпанов, В.Н. Домацкий, В.В. Белименко; ред. Н.Е. Косминков. - М.: ИНФРА-М, 2019. - 458 с. - ISBN 9785-16-014697-3.

5. Пэворд, Т. Полный ветеринарный справочник по болезням лошадей / Т. Пэворд, М. Пэворд: пер. с анг. О.Б. Аносовой, К.И. Логиновой. - М.: Аквариум-Принт, 2005.- 179 с. - ISBN 5-98435-229-X.

6. Содержание, кормление и болезни лошадей: учеб. пособие / А. А. Стекольников, А. Ф. Кузнецов, А. В. Виль [и др.]; под ред. А. А. Стекольникова. - СПб.: Лань, 2007. - 624 с. - ISBN 978-5-8114-0689-0.

7. Управление Федеральной службы по надзору в сфере прав потребителей и благополучия человека по Приморскому краю: офиц. сайт. Владивосток. - URL: www.25.rospotrebnadzor.ru (дата обращения:02.11.2020). - Текст: электронный.

8. Юров, К.П. Инфекционные и паразитарные болезни лошадей / К.П. Юров, В.Т. Заблоцкий, Н.Е. Косминков. - Зоомедлит, 2010 г. - 260 с.

9. A Review on Equine Piroplasmosis: Epidemiology, Vector Ecology, Risk Factors, Host Immunity, Diagnosis and Control / Thank God E. Onyiche, Keisuke Suganuma, Ikuo Igarashi, Naoaki Yokoyama, Xuenan Xuan, Oriel Thekisoe. - doi: 10.3390/ijerph16101736 // Int. J Environ Res Public Health. - 2019.- May, 16(10). - P.1736. - URL: https://www.ncbi.nlm.nih.gov/pmc/articles/PMC6572709/ (дата обращения: 15.11.2020). 
10. Pelzel-McCluskey, A.M. Equine Piroplasmosis / A.M. Pelzelc McCluskey, Josie L. Traub-Dargatz. - DOI: 10.1016/B978-1-4557-4555-5.00114X // Robinson's Current Therapy in Equine Medicine. - 2015. - P. 480-483.

11. Taylor, L. Equine Piroplasmosis / L. Taylor // Manual of Diagnostic Tests and Vaccines for Terristal Animals. - 2014 - P.879-889. - URL: https://www.oie.int/doc/ged/d12009.pdf (дата обращения: 15.11.2020).

(C) Е.Н. Любченко, Д.К. Болтенко, 2020 